\title{
Penentuan Tingkat Kesenjangan Wilayah Dan Faktor Penyebab Terjadinya Kesenjangan di Kabupaten Gresik
}

\author{
Novtaviana Anggraeni dan Belinda Ulfa Aulia \\ Departemen Perencanaan Wilayah dan Kota, Fakultas Arsitektur Desain dan Perencanaan, \\ Institut Teknologi Sepuluh Nopember (ITS) \\ e-mail: b3ltown@gmail.com
}

\begin{abstract}
Abstrak-Kota Surabaya merupakan salah satu kota yang memiliki perkembangan pesat dan berdampak pada wilayah yang berbatasan langsung dengan Kota Surabaya, salah satunya adalah Kabupaten Gresik. Perkembangan wilayah Kabupaten Gresik dipengaruhi oleh aktivitas dari kota inti yaitu Surabaya. Gejala pergeseran perkembangan Kota Surabaya ke wilayah Kabupaten Gresik tersebut dapat merubah karakteristik wilayah di Kabupaten Gresik dan menyebabkan salah satu permasalahan yaitu kesenjangan wilayah. Kesenjangan yang terjadi di wilayah tersebut meliputi kesenjangan pada aspek ekonomi antar kecamatan, aspek sosial, distribusi pendapatan dan akses masyarakat terhadap infrastruktur. Penelitian ini bertujuan untuk menganalisis tingkat kesenjangan yang terjadi serta faktor-faktor yang berpotensi menyebabkan terjadinya kesenjangan wilayah antar kecamatan di Kabupaten Gresik berdasarkan aspek ekonomi dan sosial. Perhitungan tingkat kesenjangan tersebut yang kemudian dijadikan dasar dalam perumusan tipologi wilayah berdasarkan tingkat kesenjangan yang akan mempermudah dalam perumusan kebijakan penanganan tingkat kesenjangan sesuai dengan faktor penyebab kesenjangan yang ditemukan. Analisis yang digunakan dalam penelitian ini adalah perhitungan Indeks Williamson sebagai rumus perhitungan kesenjangan wilayah. Adapun analisis kedua yaitu analisis korelasi menggunakan software SPSS untuk mengetahui faktor apa saja yang berpotensi menyebabkan kesenjangan di Kabupaten Gresik. Berdasarkan hasil analisis yang dilakukan dalam penelitian, terdapat 2 kecamatan yang termasuk kedalam tipologi wilayah dengan kesenjangan tinggi, 5 kecamatan yang termasuk kedalam tipologi wilayah dengan kesenjangan sedang dan 9 kecamatan yang termasuk tipologi wilayah dengan kesenjangan rendah. Faktor yang mempengaruhi terjadinya kesenjangan wilayah yang terjadi pada tiap kecamatan di Kabupaten Gresik adalah PDRB perkapita, kontribusi sektor industri tehadap PDRB, jumlah tenaga kerja industri, jumlah tenaga kerja pertanian, panjang jalan aspal, jumlah penduduk SMA, jumlah penduduk datang, jumlah fasilitas SMP, jumlah fasilitas rumah sakit dan jumlah fasilitas puskesmas.
\end{abstract}

Kata Kunci-Kesenjangan Wilayah, Tipologi Wilayah.

\section{PENDAHULUAN}

K AWASAN Gerbangkertasusila merupakan suatu kawasan yang secara administratif terpisah namun secara fisik, ekonomi dan sosial menyatu akibat adanya dampak resiprokal perekonomian Kota Surabaya terhadap Kabupaten Gresik, Bangkalan, Mojokerto, Sidoarjo dan Lamongan [1]. Penyatuan kegiatan baik secara sosial maupun ekonomi di wilayah ini dapat mengindikasikan adanya peristiwa pemekaran kawasan perkotaan, dengan Kota Surabaya sebagai kota intinya dan Kabupaten Gresik menjadi salah satu wilayah yang terkena dampak peristiwa tersebut.
Adanya perembetan kawasan perkotaan ke wilayah pinggiran tersebut mengindikasikan bahwa Kabupaten Gresik tidak terlepas dari permasalahan kesenjangan wilayah terutama dalam aspek perekonomian antar kecamatan, aspek sosial, distribusi pendapatan dan akses masyarakat terhadap infrastruktur [2]. Berdasarkan dokumen RKPD Kabupaten Gresik Tahun 2015, tingkat kesenjangan perekonomian yang terjadi dapat terlihat dari nilai hasil perhitungan Indeks Williamson Kabupaten Gresik yang menunjukkan angka kesenjangan wilayah sebesar 0,74 pada tahun 2013, 0,69 pada tahun 2014, 0,64 pada tahun 2015 dan pada tahun 2016 menunjukkan angka 0,57. Meskipun nilai Indeks Williamson (IW) tersebut cenderung mengalami penurunan, namun nilai kesenjangan di Kabupaten Gresik tersebut masih tergolong tinggi karena nilai IW > 0,5 [3].

Dalam perkembangannya, salah satu aspek yang mempengaruhi terjadinya kesenjangan antar wilayah di Kabupaten Gresik adalah aspek ekonomi. Dari segi ekonomi, kegiatan industri merupakan sektor yang mendominasi struktur ekonomi di kabupaten Gresik hingga mencapai $45,97 \%$. Berbeda dengan sektor primer yaitu pertanian yang hanya menopang sebesar $10,43 \%$ dalam perekonomian Kabupaten Gresik. Hal tersebut menyebabkan terjadinya perbedaan perekonomian di Kabupaten Gresik diantara kecamatan dengan dominasi tenaga kerja di sektor industri yang lebih mengarah ke perkotaan dengan kecamatan yang didominasi oleh tenaga kerja di bidang pertanian yang lebih mengarah ke wilayah perdesaan (Dokumen PDRB Kabupaten Gresik Menurut Lapangan Usaha Tahun 2012 2016) [4]. Kecamatan dengan jumlah tenaga kerja pada sektor industri yang tinggi adalah Kecamatan Driyorejo yaitu sebanyak 30.383 penduduk, Kecamatan Kebomas yaitu sebanyak 27.801 penduduk dan Kecamatan Manyar sebanyak 17.135 penduduk. Adapun sebagian besar industri di kabupaten Gresik terkonsentrasi di Kecamatan Kebomas, Kecamatan Manyar dan Kecamatan Gresik. Sedangkan kecamatan dengan jumlah penduduk yang bekerja pada sektor pertanian yang besar adalah Kecamatan Menganti sebanyak 23.122 penduduk, Kecamatan Kedamean sebanyak 18.780 penduduk dan Kecamatan Benjeng sebanyak 13.922 penduduk [5].

Selain aspek ekonomi, indikasi timbulnya kesenjangan wilayah berdasarkan aspek sosial dapat dilihat dari tingkat kesejahteraan masyarakat [6]. Apabila ditinjau dari segi kemiskinan, tingkat kemiskinan di Kabupaten Gresik masih tergolong tinggi yaitu menembus angka $13,19 \%$ atau sekitar 167.120 warga miskin (Bappeda Kabupaten Gresik) [7]. Angka kemiskinan tersebut dikatakan tinggi dikarenakan Pemerintah Kabupaten Gresik mentargetkan pengentasan kemiskinan di ditekan hingga dibawah presentase $10 \%$ pada 
tahun 2016. Berdasarkan data BPS Kabupaten Gresik tahun 2016, jumlah keluarga Pra Sejahtera juga dapat dijadikan ukuran terjadinya kesenjangan wilayah antar kecamatan di kabupaten Gresik. Kecamatan dengan jumlah keluarga Pra Sejahtera tertinggi adalah Kecamatan Menganti yaitu sebesar 35.898 KK dan jumlah keluarga Pra Sejahtera terendah adalah Kecamatan Gresik yaitu sebesar 774 KK [5].

Berdasarkan penjabaran data, fakta dan masalah terkait kesenjangan wilayah di Kabupaten Gresik, maka perlu adanya penelitian untuk mengetahui tipologi wilayah berdasarkan tingkat kesenjangan yang terjadi antar kecamatan di Kabupaten Gresik serta faktor apa saja yang berpengaruh terhadap terjadinya kesenjangan wilayah di Kabupaten Gresik berdasarkan aspek sosial dan ekonomi. Tipologi wilayah tersebut dapat dijadikan sebagai bahan pertimbangan dalam perumusan kebijakan penanganan kesenjangan berdasarkan kebutuhan setiap tipologi yang terbentuk serta faktor yang berpotensi berpengaruh terhadap terjadinya kesenjangan wilayah.

\section{METODE PENELITIAN}

\section{A. Jenis dan Pendekatan Penelitian}

Pendekatan yang digunakan dalam penelitian ini adalah pendekatan rasionalistik positivistik. Jenis penelitian dalam penelitian ini adalah penelitian kuantitatif [8].

\section{B. Variabel Penelitian}

Variabel penelitian yang digunakan untuk mengidentifikasi tingkat kesenjangan wilayah tiap kecamatan di Kabupaten Gresik antara lain adalah jumlah penduduk dan PDRB per kapita.

Variabel penelitian yang digunakan untuk penentuan faktor apa saja yang berpengaruh terhadap terjadinya kesenjangan wilayah dibagi kedalam dua aspek yaitu aspek ekonomi dan aspek sosial, adapun variabel penelitian dari aspek ekonomi adalah PDRB per kapita, kontribusi sektor industri terhadap PDRB, kontribusi sektor pertanian terhadap PDRB, jumlah tenaga kerja sektor industri, jumlah tenaga kerja sektor pertanian dan panjang jalan aspal. Sedangkan variabel dari aspek sosial adalah tingkat pendidikan penduduk SD, tingkat pendidikan penduduk SMP, tingkat pendidikan penduduk SMA, jumlah penduduk datang, ketersediaan fasilitas rumah sakit, ketersediaan fasilitas puskesmas, ketersediaan fasilitas pendidikan SD, ketersediaan fasilitas pendidikan SMP, ketersediaan fasilitas pendidikan SMA serta jumlah keluarga pra sejahtera.

C. Mengidentifikasi Tingkat Kesenjangan Wilayah yang Terjadi pada Tiap Kecamatan di Kabupaten Gresik

Analisis yang digunakan dalam identifikasi tingkat kesenjangan wilayah di tiap kecamatan adalah menggunakan perhitungan Indeks Williamson. berdasarkan data PDRB per kapita dan jumlah penduduk. Adapun rumus perhitungan Indeks Williamson sebagai berikut: [9]

Keterangan

$$
C V_{w}=\frac{\sqrt{\sum(Y i-y)^{2} \mathrm{fi} / \mathbf{n}}}{\mathrm{y}}
$$

$\mathrm{CVw}=$ Indeks Williamson

$\mathrm{f} i \quad=$ Jumlah penduduk Kecamatan $i$ (jiwa)

$\mathrm{n} \quad=$ Jumlah penduduk Kabupaten Gresik (jiwa)

$Y i=$ PDRB per kapita Kecamatan $i$ (Rupiah)

$\overline{\mathrm{y}}=$ PDRB per kapita rata-rata Kabupaten Gresik (Rupiah)
Adapun kriteria interpretasi dari nilai Indeks Williamson sebagai berikut:

1. Apabila nilai IW $<0,35$ maka kesenjangan yang terjadi rendah.

2. Apabila $0,35 \leq \mathrm{IW} \leq 0,5$ maka kesenjangan yang terjadi sedang.

3. Apabila nilai IW $>0,5$ maka kesenjangan yang terjadi tinggi.

Setelah dilakukan penentuan tingkat kesenjangan wilayah yang terjadi di setiap kecamatan, kemudian dilakukan pengelompokkan wilayah berdasarkan tingkat kesenjangan menjadi wilayah dengan kesenjangan rendah, wilayah dengan kesenjangan sedang dan wilayah dengan kesenjangan tinggi.

D. Menganalisis Faktor-Faktor yang Berpengaruh Terhadap Terjadinya Kesenjangan Wilayah di Kabupaten Gresik Berdasarkan Aspek Sosial dan Ekonomi

Dalam analisis penentuan faktor apa saja yang berpengaruh terhadap terjadinya kesenjangan wilayah di kabupaten Gresik digunakan analisis korelasi dengan bantuan software SPSS 17. Adapun analisis korelasi menggunakan bantuan SPSS 17 dengan tahapan-tahapannya adalah sebagai berikut: [8]

1. Masukkan data berdasarkan variabel aspek sosial dan aspek ekonomi serta data nilai kesenjangan tiap kecamatan kedalam software SPSS 17.

2. Klik Anlyze - Correlate - Bivariate

3. Masukkan data nilai kesenjangan wilayah dan data variabel aspek sosial dan ekonomi kedalam kolom Variables. Centang Pearson pada Kolom Correlation Coefficients. Dan Pilih Two-tailed pada kolom Test of Significant. Centang kolom Flag significant of correlations.

4. Klik Options. Centang Means and standard deviations pada kolom Statistics. Pilih Exclude cases pairwise pada kolom Missing Values.

5. Klik OK. Akan menghasilkan output tabel.

Setelah dilakukan analisis, dilakukan interpretasi terhadap hasil korelasi antara masing-masing variabel penyebab kesenjangan dengan nilai kesenjangan wilayah. Apabila nilai Signifikansi < 0,05 maka Ho ditolak, berarti terdapat hubungan yang signifikan antara nilai kesenjangan wilayah dengan variabel penyebab kesenjangan.

\section{HASIL DAN DISKUSI}

A. Mengidentifikasi Tingkat Kesenjangan Wilayah yang Terjadi pada Tiap Kecamatan di Kabupaten Gresik

Analisis pertama yang dilakukan dalam penelitian ini adalah penentuan nilai kesenjangan wilayah tiap kecamatan di Kabupaten Gresik. Alat analisis yang digunakan untuk mengetahui besarnya nilai kesenjangan wilayah adalah perhitungan dengan menggunakan Indeks Williamson. Perhitungan tersebut dilakukan dengan menggunakan data utama yaitu PDRB per kapita tiap kecamatan, data jumlah penduduk tiap kecamatan serta data jumlah penduduk kabupaten.

Perhitungan data PDRB per kapita didapatkan dengan mambagi data PDRB kecamatan dengan jumlah penduduk pada kecamatan yang dihitung. Dalam penelitian ini, peneliti tidak memperoleh data PDRB kecamatan dikarenakan data tersebut tidak diolah oleh pihak penyedia data perekonomian 

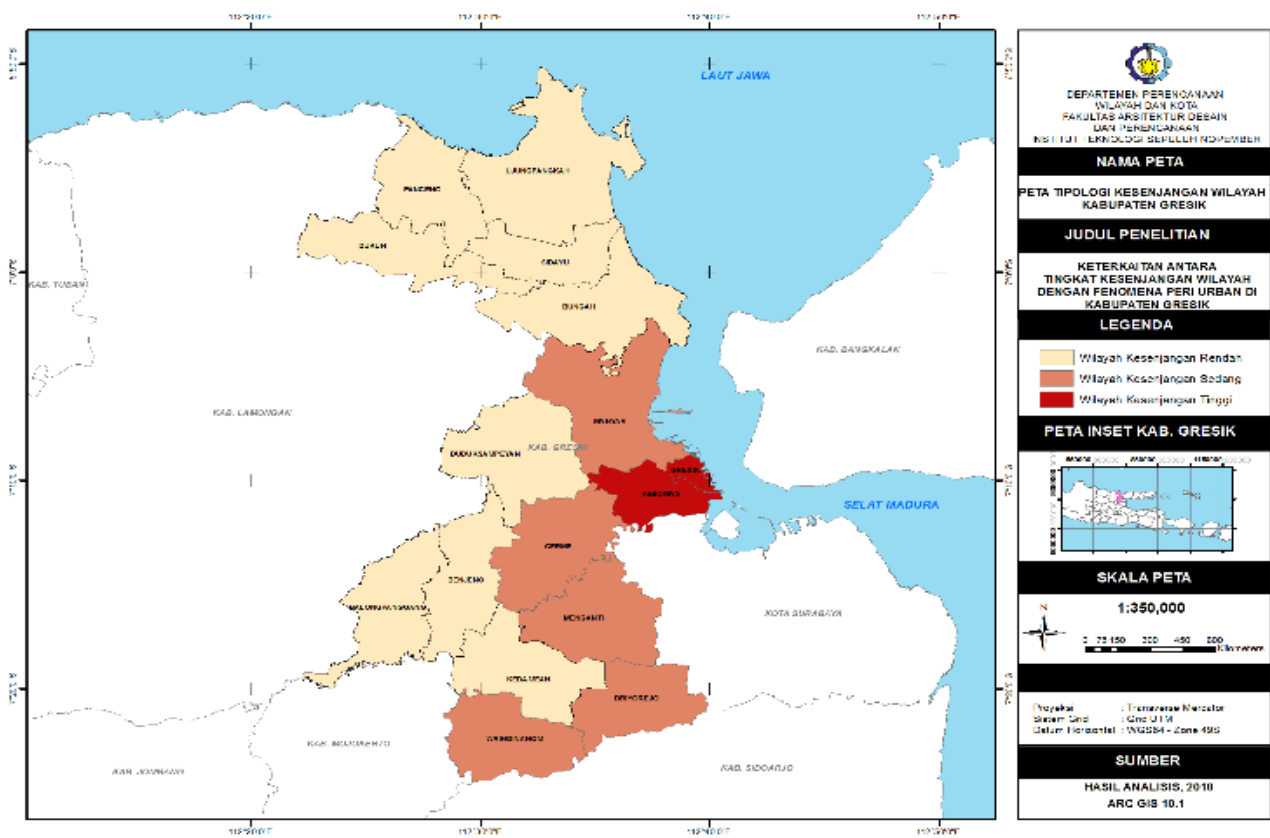

Gambar 1. Peta Tipologi Wilayah Berdasarkan Tingkat Kesenjangan di Kabupaten Gresik.

dari Pemerintah Kabupaten Gresik. Hal tersebut kemudian yang melatarbelakangi adanya referensi untuk menghitung PDRB kecamatan dengan metode tidak langsung yaitu metode perhitungan dengan cara alokasi, yaitu menurunkan nilai PDRB kabupaten ke PDRB kecamatan dengan menggunakan berbagai macam indikator sebagai alokator yang mempunyai pengaruh paling erat dengan kegiatan ekonomi wilayah penelitian. Salah satu alokator yang digunakan untuk menghitung PDRB kecamatan pada wilayah penelitian adalah indikator jumlah tenaga kerja [10]. Adapun rumus perhitungan yang digunakan adalah sebagai berikut.

$$
P D R B_{\text {kecamatan }}=\text { Share tenaga kerja kecamatan } * P D R B \text { kabupaten }
$$

Dalam perhitungan share tenaga kerja tiap kecamatan tersebut, peneliti membagi data tenaga kerja kedalam 3 kelompok yaitu tenaga kerja sektor primer, tenaga kerja sektor sekunder dan tenaga kerja sektor tersier. Begitu pula dengan data PDRB kabupaten juga dibagi kedalam data PDRB sektor primer, PDRB sektor sekunder dan PDRB sektor tersier. Hal tersebut dilakukan karena perbedaan yang sangat mencolok antara produktivitas dari sektor primer, sektor sekunder dan sektor tersier Kabupaten Gresik sehingga membentuk nilai PDRB yang memiliki perbedaan cukup jauh. Share tenaga kerja dalam perhitungan ini merepresentasikan proporsi pembagian nilai PDRB setiap kecamatan dari PDRB tingkat kabupaten tiap sektor. Adapun besaran nilai PDRB Kabupaten Gresik tiap sektor yang akan diturunkan kedalam perhitungan data PDRB level kecamatan adalah sebagai berikut [11].

Tabel 1.

Pembagian Nilai PDRBKabupaten Gresik tiap Sektor[4]

\begin{tabular}{|c|c|c|}
\hline No & Sektor & PDDB Kabupaten (Rp) \\
\hline 1 & Sektor Primer (Pertanian) & 9.038 .999 .000 \\
\hline 2 & Sektor Sekunder (Industri Pengolahan) & 52.567 .458 .800 \\
\hline 3 & Sektor Tersier & 39.917 .677 .100 \\
\hline & Total & 101.524 .134 .900 \\
\hline
\end{tabular}

Setelah nilai PDRB kabupaten tiap sektor tersebut dikalikan dengan share tenaga kerja tiap sektor pada kecamatan, maka didapatkan hasil PDRB kecamatan tiap sektor yang kemudian dijumlahkan dan menghasilkan PDRB kecamatan total dari 16 kecamatan di Kabupaten Gresik. Adapun nilai total PDRB kecamatan tersebut dapat dilihat pada tabel sebagai berikut.
Tabel 2.

PDRB Kecamatan di Kabupaten Gresik

\begin{tabular}{clr}
\hline \hline No & Kecamatan & PDRB Kecamatan (Rupiah) \\
\hline 1 & Balongpanggang & 4.478 .079 .322 \\
2 & Benjeng & 3.992 .890 .648 \\
3 & Bungah & 2.527 .064 .574 \\
4 & Cerme & 9.473 .612 .524 \\
5 & Driyorejo & 11.432 .272 .511 \\
6 & Duduksampeyan & 3.008 .256 .934 \\
7 & Dukun & 945.409 .307 \\
8 & Gresik & 8.632 .626 .470 \\
9 & Kebomas & 11.766 .408 .458 \\
10 & Kedamean & 4.695 .938 .172 \\
11 & Manyar & 9.692 .363 .247 \\
12 & Menganti & 10.676 .579 .029 \\
13 & Panceng & 1.754 .092 .299 \\
14 & Sidayu & 3.439 .113 .177 \\
15 & Ujungpangkah & 2.597 .320 .997 \\
16 & Wringinanom & 6.698 .049 .939 \\
\hline \hline
\end{tabular}

Setelah diketahui nilai PDRB kecamatan, maka dapat dihitung nilai PDRB perkapita dengan membagi nilai total PDRB kecamatan dengan data jumlah keseluruhan penduduk. Kemudian dilakukan analisis nilai kesenjangan wilayah dengan menggunakan perhitungan Indeks Williamson. Hasil perhitungan nilai kesenjangan wilayah dari setiap kecamatan di Kabupaten Gresik dapat dilihat pada tabel sebagai berikut.

Tabel 3.

Nilai Kesenjangan Wilayah tiap Kecamatan di Kabupaten Gresik

\begin{tabular}{clc}
\hline \hline No & Kecamatan & Nilai Kesenjangan Wilayah (IW) \\
\hline 1 & Balongpanggang & 0,19 \\
2 & Benjeng & 0,24 \\
3 & Bungah & 0,32 \\
4 & Cerme & 0,47 \\
5 & Driyorejo & 0,43 \\
6 & Duduksampeyan & 0,21 \\
7 & Dukun & 0,12 \\
8 & Gresik & 0,91 \\
9 & Kebomas & 0,53 \\
10 & Kedamean & 0,23 \\
11 & Manyar & 0,39 \\
12 & Menganti & 0,37 \\
13 & Panceng & 0,32 \\
14 & Sidayu & 0,10 \\
15 & Ujungpangkah & 0,11 \\
16 & Wringinanom & 0,38 \\
\hline \hline
\end{tabular}


Tabel 5.

Hasil Analisis Korelasi Variabel Aspek Ekonomi yang Berpengaruh terhadap Kesenjangan Wilayah

\begin{tabular}{|c|c|c|c|c|}
\hline Variabel y & Variabel $\mathrm{x}$ & Signifikansi & $\begin{array}{c}\text { Pearson } \\
\text { Correlation }\end{array}$ & Keterangan \\
\hline \multirow{8}{*}{$\begin{array}{c}\text { Nilai } \\
\text { Kesenjangan } \\
\text { Wilayah }\end{array}$} & PDRB per & 0,021 & 0,572 & Berpengaruh \\
\hline & kapita & & & \\
\hline & $\begin{array}{l}\text { Kontribusi } \\
\text { sektor } \\
\text { industri } \\
\text { terhadap } \\
\text { PDRB }\end{array}$ & 0,023 & 0,564 & Berpengaruh \\
\hline & $\begin{array}{l}\text { Kontribusi } \\
\text { sektor } \\
\text { pertanian } \\
\text { terhadap }\end{array}$ & 0,714 & $-0,100$ & $\begin{array}{l}\text { Tidak } \\
\text { Berpengaruh }\end{array}$ \\
\hline & $\begin{array}{l}\text { PDRB } \\
\text { Jumlah }\end{array}$ & 0,023 & 0,564 & Berpengaruh \\
\hline & $\begin{array}{l}\text { tenaga kerja } \\
\text { sektor } \\
\text { industri }\end{array}$ & & & \\
\hline & $\begin{array}{l}\text { Jumlah } \\
\text { tenaga kerja } \\
\text { sektor } \\
\text { pertanian }\end{array}$ & 0,039 & $-0,521$ & $\begin{array}{l}\text { Berpengaruh } \\
\text { Negatif }\end{array}$ \\
\hline & $\begin{array}{l}\text { Panjang Jalan } \\
\text { Aspal }\end{array}$ & 0,004 & 0,672 & Berpengaruh \\
\hline
\end{tabular}

Adapun kriteria interpretasi dari nilai Indeks Williamson sebagai berikut:

1. Apabila nilai IW $<0,35$ maka kesenjangan yang terjadi rendah.

2. Apabila nilai $0,35 \leq \mathrm{IW} \leq 0,5$ maka kesenjangan yang terjadi sedang.

3. Apabila nilai IW >0,5 maka kesenjangan yang terjadi tinggi.

Berdasarkan hasil dari tabel dan dibandingkan dengan kriteria interpretasi tersebut, maka didapatkan hasil tipologi atau pengelompokkan wilayah berdasarkan nilai kesenjangan wilayah sebagai berikut.

1. Wilayah dengan Tingkat Kesenjangan Rendah

Nilai kesenjangan rendah berdasarkan Indeks Williamson apabila nilai IW $<0,35$. Kecamatan yang tergolong kedalam kecamatan dengan nilai kesenjangan wilayah rendah sesuai hasil perhitungan Indeks Williamson di Kabupaten Gresik adalah Kecamatan Balongpanggang, Kecamatan Bungah, Kecamatan Benjeng, Kecamatan Duduksampeyan, Kecamatan Dukun, Kecamatan Kedamean, Kecamatan Panceng, Kecamatan Sidayu dan Kecamatan Ujungpangkah.

Hal tersebut dikarenakan kecamatan yang termasuk kedalam tipologi wilayah dengan kesenjangan rendah tersebut mayoritas penduduk memiliki jenis pekerjaan yang homogen dan didominasi oleh penduduk yang bekerja pada sektor primer/ pertanian. Selain itu, jumlah penduduk dan pertumbuhan penduduk di wilayah kecamatan dengan kesenjangan rendah ini masih tergolong rendah. Hal tersebut mengindikasikan adanya kemerataan atau kesamaan tingkat pendapatan dan tingkat kesejahteraan penduduk sehingga tidak terlalu terlihat gap atau kesenjangan antar wilayah di kecamatan yang termasuk dalam tipologi ini.

\section{Wilayah dengan Tingkat Kesenjangan Sedang}

Berdasarkan ketentuan nilai Indeks Williamson, daerah yang dikatakan memiliki nilai kesenjangan sedang apabila nilai IW berkisar antara 0,35 sampai dengan 0,5. Berdasarkan hasil diatas, maka kecamatan di Kabupaten Gresik yang tergolong kedalam wilayah dengan nilai kesenjangan sedang antara lain adalah Kecamatan Cerme, Kecamatan Driyorejo, Kecamatan Manyar, Kecamatan Menganti dan Kecamatan Wringinanom.
Tabel 4.

Hasil Analisis Korelasi Variabel Aspek Sosial yang Berpengaruh terhadap Kesenjangan Wilayah

\begin{tabular}{|c|c|c|c|c|}
\hline Variabel y & Variabel $\mathrm{x}$ & Signifikansi & $\begin{array}{c}\text { Pearson } \\
\text { Correlation }\end{array}$ & Keterangan \\
\hline \multirow{13}{*}{$\begin{array}{c}\text { Nilai } \\
\text { Kesenjangan } \\
\text { Wilayah }\end{array}$} & Jumlah & 0,838 & 0,056 & Tidak \\
\hline & Penduduk SD & & & Berpengaruh \\
\hline & Jumlah & 0,144 & 0,382 & Tidak \\
\hline & $\begin{array}{l}\text { penduduk SMP } \\
\text { Jumlah }\end{array}$ & 0,008 & 0,641 & $\begin{array}{l}\text { Berpengaruh } \\
\text { Berpengaruh }\end{array}$ \\
\hline & $\begin{array}{l}\text { Penduduk } \\
\text { SMA }\end{array}$ & & & \\
\hline & $\begin{array}{l}\text { Jumlah } \\
\text { penduduk } \\
\text { datang }\end{array}$ & 0,002 & 0,707 & Berpengaruh \\
\hline & Jumlah & 0,612 & $-0,137$ & Tidak \\
\hline & $\begin{array}{l}\begin{array}{l}\text { keluarga } \\
\text { sejahtera }\end{array} \\
\text { pra }\end{array}$ & & & Berpengaruh \\
\hline & $\begin{array}{l}\text { Jumlah fasilitas } \\
\text { SD }\end{array}$ & 0,284 & 0,286 & $\begin{array}{l}\text { Tidak } \\
\text { Berpengaruh }\end{array}$ \\
\hline & $\begin{array}{l}\text { Jumlah fasilitas } \\
\text { SMP }\end{array}$ & 0,003 & 0,700 & Berpengaruh \\
\hline & $\begin{array}{l}\text { Jumlah fasilitas } \\
\text { SMA }\end{array}$ & 0,088 & 0,440 & $\begin{array}{l}\text { Tidak } \\
\text { Berpengaruh }\end{array}$ \\
\hline & $\begin{array}{l}\text { Jumlah fasilitas } \\
\text { rumah sakit }\end{array}$ & 0,008 & 0,641 & Berpengaruh \\
\hline & $\begin{array}{l}\text { Jumlah fasilitas } \\
\text { puskesmas }\end{array}$ & 0,030 & 0,541 & Berpengaruh \\
\hline
\end{tabular}

Dalam tipologi wilayah dengan tingkat kesenjangan sedang ini, heterogenitas pekerjaan penduduk mulai terlihat antara penduduk yang bekerja di sektor primer, sektor sekunder dan tersier. Dalam satu wilayah kecamatan, terdapat beberapa desa dengan jumlah penduduk yang bekerja di sektor primer lebih tinggi dibandingkan dengan jumlah penduduk yang bekerja di sektor sekunder maupun tersier. Begitu pula sebaliknya, terdapat desa dengan jumlah penduduk yang bekerja di sektor sekunder atau tersier lebih tinggi dibandingkan jumlah penduduk yang bekerja di sektor primer. Adapun jumlah penduduk dan pertumbuhan penduduk pada wilayah dengan kesenjangan sedang ini cukup tinggi. Hal tersebut yang kemudian mulai mengindikasikan adanya perbedaan pemerataan ekonomi dalam satu wilayah kecamatan sehingga memunculkan gap atau kesenjangan dalam wilayah kecamatan tersebut.

3. Wilayah dengan Tingkat Kesenjangan Tinggi

Berdasarkan ketentuan nilai Indeks Williamson, daerah yang dikatakan memiliki nilai kesenjangan sedang apabila nilai IW diatas 0,5. Berdasarkan hasil diatas, maka kecamatan di Kabupaten Gresik yang tergolong kedalam wilayah dengan nilai kesenjangan sedang antara lain Kecamatan Gresik dan Kecamatan Kebomas. Hal tersebut dikarenakan kecamatan yang termasuk kedalam tipologi wilayah dengan kesenjangan tinggi tersebut mayoritas penduduk memiliki jenis pekerjaan yang heterogen dan didominasi oleh penduduk yang bekerja pada sektor sekunder serta tersier. Akan tetapi, juga masih terdapat beberapa penduduk desa dari Kecamatan Gresik dan Kebomas yang bekerja di sektor primer/pertanian. Adapun jumlah penduduk serta pertumbuhan penduduk terutama penduduk datang pada wilayah ini tergolong sangat tinggi dan berlangsung cepat. Hal tersebut yang kemudian mengindikasikan adanya ketidakmertaan tingkat pendapatan dan tingkat kesejahteraan penduduk sehingga terlihat gap atau kesenjangan yang cukup tinggi antar wilayah di dalam kecamatan yang termasuk dalam tipologi ini.

Adapun peta tipologi wilayah berdasarkan tingkat kesenjangan tiap kecamatan di Kabupaten Gresik dapat dilihat pada Gambar 1. 


\section{B. Menganalisis Faktor-Faktor yang Berpengaruh} Terhadap Terjadinya Kesenjangan Wilayah di Kabupaten Gresik Berdasarkan Aspek Sosial dan Ekonomi

Analisis yang dilakukan selanjutnya adalah analisis korelasi. Analisis tersebut digunakan untuk mengetahui faktor apa saja yang berpengaruh terhadap tingkat kesenjangan wilayah yang terjadi di tiap kecamatan di Kabupaten Gresik. Analisis korelasi dilakukan dengan menghitung nilai signifikansi dan tingkat korelasi antara nilai kesenjangan wilayah (IW) dengan variabel-variabel penyebab kesenjangan wilayah dari aspek ekonomi dan sosial.

Setelah melakukan running data melalui software SPSS 17, hasil analisis dari korelasi dapat dilihat dengan menggunakan hasil nilai signifikasni dan nilai pearson correlation. Variabel yang memiliki pengaruh terhadap nilai kesenjangan wilayah adalah variabel yang memiliki nilai signifikansi kurang dari 0,05 .

Kemudian tingkat hubungan yang terjadi antara variabel dengan nilai kesenjangan wilayah dpaat diketahui dari nilai Pearson Correlation. Apabila nilai Pearson Correlation semakin besar dan mendekati angka 1, maka hubungan korelasi yang terjadi antara variabel dengan kesenjangan wilayah semakin kuat. Selain itu, jika nilai Pearson Correlation menunjukkan angka negatif maka hubungan korelasi yang terjadi antara variabel dengan nilai kesenjangan wilayah bersifat berbanding terbalik. Akan tetapi, jika nilai Pearson Correlation menunjukkan angka positif maka sifat hubungan antar variabel dengan nilai kesenjangan wilayah bersifat berbanding lurus. Adapun hasil korelasi tiap variabel dengan nilai kesenjangan dapat dilihat pada Tabel 4 dan 5 .

Berdasarkan tabel 4 dan 5, maka penjelasan variabel yang berpengaruh terhadap nilai kesenjangan wilayah (IW) tiap kecamatan di Kabupaten Gresik adalah sebagai berikut.

1. Aspek Ekonomi

a. PDRB per kapita memiliki nilai korelasi positif sebesar 0,572. Hal ini berarti, peningkatan PDRB per kapita pada suatu wilayah di tiap kecamatan berpotensi meningkatkan kesenjangan wilayah yang terjadi antar kecamatan yang berada dalam setiap tipologi wilayah peri urban. Begitu pula sebaliknya, jika terjadi penurunan PDRB per kapita berpotensi dapat menurunkan nilai kesenjangan wilayah yang terjadi.

b. Kontribusi sektor industri terhadap PDRB memiliki nilai korelasi positif sebesar 0,564. Hal tersebut menunjukkan bahwa apabila kontribusi sektor industri terhadap PDRB pada suatu wilayah semakin meningkat maka dapat berpotensi pula terhadap terjadinya peningkatan kesenjangan antar wilayah. Begitu pula sebaliknya, jika kontribusi sektor industri semakin menurun maka kesenjangan wilayah yang terjadi juga berpotensi akan berkurang.

c. Jumlah tenaga kerja sektor industri memiliki nilai korelasi positif sebesar 0,564 . Semakin meningkatnya pekerja di sektor industri pada suatu wilayah maka berpotensi meningkatkan kesenjangan wilayah yang terjadi antar kecamatan dalam tiap tipologi peri urban di Kabupaten Gresik. Begitu pula sebaliknya, semakin berkurangnya pekerja industri maka kesenjangan wilayah berpotensi semakin menurun.

d. Jumlah tenaga kerja pertanian memiliki nilai korelasi negatif sebesar 0,521. Hal tersebut menunjukkan bahwa semakin meningkatnya penduduk yang bekerja di sektor pertanian maka kesenjangan wilayah yang terjadi berpotensi semakin menurun. Sebaliknya, apabila pekerja pertanian suatu wilayah semakin menurun maka kesenjangan yang terjadi berpotensi akan semakin meningkat.

e. Panjang jalan aspal memiliki nilai korelasi positif sebesar 0,672 . Hal tersebut menunjukkan bahwa jika suatu wilayah memiliki peningkatan penyediaan jalan aspal maka dapat berpotensi menyebabkan kesenjangan wilayah yang terjadi dengan wilayah lain juga semakin meningkat.

2. Aspek Sosial

a. Jumlah penduduk SMA memiliki nilai korelasi positif yaitu sebesar 0,641. Hal tersebut menunjukkan bahwa wilayah yang memiliki semakin banyak penduduk yang melaksanakan pendidikan SMA maka akan berpotensi terjadinya peningkatan kesenjangan dengan wilayah lain pada kecamatan di tiap tipologi wilayah peri urban. Begitu pula sebaliknya.

b. Jumlah penduduk datang memiliki nilai korelasi positif sebesar 0,707. Hal tersebut menunjukkan bahwa semakin terjadinya peningkatan perpindahan penduduk pada suatu wilayah maka akan berpotensi meningkatkan pula kesenjangan antar wilayah yang terjadi pada setiap tipologi wilayah peri urban di Kabupaten Gresik. Begitu pula sebaliknya, apabila jumlah penduduk datang menurun atau sedikit, maka kesenjangan yang terjadi berpotensi menurun.

c. Jumlah fasilitas SMP memiliki nilai korelasi positif sebesar 0,700. Hasil tersebut menunjukkan bahwa adanya peningkatan jumlah ketersediaan fasilitas pendidikan berupa SMP pada suatu wilayah maka berpotensi akan meningkatkan kesenjangan wilayah yang terjadi.

d. Jumlah fasilitas rumah sakit memiliki nilai korelasi positif sebesar 0,641. Hasil tersebut menunjukkan bahwa adanya peningkatan jumlah ketersediaan fasilitas kesehatan berupa rumah sakit pada suatu wilayah maka berpotensi akan meningkatkan pula kesenjangan wilayah yang terjadi.

e. Jumlah fasilitas puskesmas memiliki nilai korelasi positif sebesar 0,541. Hasil tersebut menunjukkan bahwa semakin meningkatnya jumlah puskesmas di suatu wilayah maka berpotensi akan meningkatkan pula kesenjangan wilayah yang terjadi.

\section{KESIMPULAN}

Tipologi wilayah berdasarkan tingkat kesenjangan wilayah tiap kecamatan di Kabupaten Gresik dapat dibedakan menjadi tiga kelompok berikut.

a. Wilayah dengan nilai kesenjangan rendah yaitu Kecamatan Balongpanggang, Kecamatan Bungah, Kecamatan Benjeng, Kecamatan Duduksampeyan, Kecamatan Dukun, Kecamatan Kedamean, Kecamatan Panceng, Kecamatan Sidayu dan Kecamatan Ujungpangkah.

b. Wilayah dengan nilai kesenjangan sedang yaitu Kecamatan Cerme, Kecamata Driyorejo, Kecamatan Manyar, Kecamatan Meganti dan Kecamatan Wringinanom.

c. Wilayah dengan nilai kesenjangan tinggi yaitu Kecamatan Kebomas dan Kecamatan Gresik.

Faktor aspek ekonomi yang mempengaruhi terjadinya kesenjangan wilayah tiap kecamatan di Kabupaten Gresik adalah PDRB perkapita, kontribusi sektor industri tehadap PDRB, jumlah tenaga kerja industri, jumlah tenaga kerja 
pertanian dan panjang jalan aspal. Sedangkan faktor dari aspek sosial yang berpengaruh terhadap kesenjangan adalah jumlah penduduk SMA, jumlah penduduk datang, jumlah fasilitas SMP, jumlah fasilitas rumah sakit dan jumlah fasilitas puskesmas.

\section{DAFTAR PUSTAKA}

[1] N. Meiriya, "Pola Pengendalian Perkembangan Kawasan MegaUrbanisasi Gerbangkertasusila Plus," Surabaya, 2011.

[2] Badan Perencanaan Pembangunan Daerah (Bappeda) Kabupaten Gresik, "Rencana Tata Ruang Wilayah (RTRW) Kabupaten Gresik Tahun 2010-2030," Gresik, 2010.

[3] RKPD Kabupaten Gresik, "Rancangan Kerangka Ekonomi Daerah dan Kebijakan Keuangan Daerah,” Gresik, 2015.
[4] Badan Pusat Statistik Kabupaten Gresik, "PDRB Kabupaten Gresik Menurut Lapangan Usaha Tahun 2012 - 2016," Gresik, 2016.

[5] Badan Pusat Statistik Kabupaten Gresik, "Kecamatan Dalam Angka 2017," Gresik, 2017.

[6] F. Basri, Perekonomian Indonesia: Tantangan dan Harapan bag Kebijakan Ekonomi Indonesia. Jakarta: Erlangga, 2002

[7] Badan Pusat Statistik Kabupaten Gresik, "Kabupaten Gresik Dalam Angka 2017," Gresik, 2017.

[8] C. Susetyo, “Teknik Analisa Kuantitatif," Surabaya, 2017.

[9] J. Williamson, Industrialization, Inequality and Economic Growth. United Kingdom: Elgar Publishing Limited, 1997.

[10] Badan Pusat Statistik Kabupaten Bandung, "Produk Domestik Regional Bruto Kecamatan Kabupaten Bandung Tahun 2008,' Bandung, 2008.

[11] M. Fajar, Estimasi PDRB Nominal Level Kecamatan di Kabupaten Waropen. Semarang: ResearchGate, 2014. 